\title{
AN ANALYTICAL STUDY OF EPIDEMIOLOGY AND CLINICO-PATHOLOGICAL PATTERN OF CARCINOMA OESOPHAGUS IN A RURAL TERTIARY CENTRE
}

Kothandapani Selvakumar1, Thiagraj Natraj², Karunamoorthy Rajachidambaram³

${ }^{1}$ Assistant Professor, Department of General Surgery, Chennai Medical College Hospital \& Research Centre, Irungalur, Trichy.

${ }^{2}$ Assistant Professor, Department of General Surgery, Karpagam Faculty of Medical Sciences, Coimbatore.

${ }_{3}^{3}$ Associate Professor, Department of General Surgery, Chennai Medical College Hospital \& Research Centre, Irungalur, Trichy.

ABSTRACT
Oesophageal cancer is one of the least studied and deadliest cancers worldwide, because of its aggressive nature. It ranks sixth
among all cancers in mortality.

\section{AIMS AND OBJECTIVES/THE AIMS OF THIS STUDY IS TO ANALYSE AND STUDY}

1. The incidence of carcinoma oesophagus, age and sex wise; 2 . The clinical presentation of carcinoma oesophagus; 3 . The common sites of occurrence; 4 . The pathological pattern of carcinoma oesophagus.

\section{METHODS/PLACE OF STUDY}

Department of General Surgery, Chennai Medical College Hospital, Irungalur, Trichy.

\section{METHOD OF COLLECTION OF DATA}

A retrospective analytical study of 76 patients, diagnosed with carcinoma oesophagus, admitted in Surgery Department was done and study period was from April 2010 to March 2016.

\section{INCLUSION CRITERIA/ALL AGE GROUPS}

1. Both male and female; 2. Patients proven Ca Oesophagus endoscopically.

\section{EXCLUSION CRITERIA}

1. Benign strictures of oesophagus. 2. Advanced Ca Oesophagus patients.

\section{RESULTS}

Among 76 patients with carcinoma oesophagus, males of $6^{\text {th }}$ decade were more prevalent; 71 patients presented with dysphagia (85.4\%), the most common symptom. Mild oesophagus (38/76 patients) being the commonest site. Squamous cell cancer formed 67 (89\%) of all cancers.

\section{CONCLUSION}

Epidemiology of cancer oesophagus in our centre was similar to incidence worldwide. Clinically, dysphagia and weight loss were most common symptoms. Due to its aggressive nature and late stage of presentation increases the mortality worldwide.

\section{KEYWORDS}

Dysphagia, Endoscopic Evaluation, Carcinoma Oesophagus, Squamous Cell Cancer of Oesophagus.

HOW TO CITE THIS ARTICLE: Selvakumar K, Natraj T, Rajachidambaram K. An analytical study of epidemiology and clinicopathological pattern of carcinoma oesophagus in a rural tertiary centre. J. Evolution Med. Dent. Sci. 2016;5(46):2900-2903, DOI: $10.14260 /$ jemds/2016/676

\section{INTRODUCTION}

Carcinoma of the oesophagus is one among the most challenging problems confronted by the oncologic surgeon. Oesophageal tumours are highly likely to result in early mortality owing to the likelihood of advanced disease at the time of diagnosis and the challenging nature of their treatment. Survival rates have not improved significantly in 25 years, despite the availability of new treatment modalities.

Financial or Other, Competing Interest: None.

Submission 04-04-2016, Peer Review 07-05-2016,

Acceptance 12-05-2016, Published 08-06-2016.

Corresponding Author:

Dr. Kothandapani Selvakumar,

Assistant Professor

Department of General Surgery,

Chennai Medical College Hospital \& Research Centre,

Irungalur,

Trichy-621105.

E-mail: drkrajachidambaram@gmail.com

DOI: $10.14260 /$ jemds/2016/676
Squamous cell carcinomas are the most common malignancies of the oesophagus worldwide. However, adenocarcinomas of the oesophagus and cardia are relatively common, particularly in the western hemisphere. The reported incidence of these cancers is increasing in the United States at a rate surpassing that of any other cancer.

\section{AIMS OF THE STUDY \\ The Aims of this Study were to Analyse and Study \\ 1. The incidence of carcinoma oesophagus, age and sex wise. \\ 2. The clinical presentation of carcinoma oesophagus. \\ 3. The common sites of occurrence. \\ 4. The pathological pattern of carcinoma oesophagus at Chennai Medical College and Hospital, Irungalur, Trichy.}

\section{MATERIALS AND METHODS}

This study consists of 76 cases of Ca oesophagus who were admitted at Chennai Medical College and Hospital between November 2013 and November 2015. These patients were 
examined in detail as per the proforma prepared for this study. The patients were investigated to confirm the pathological diagnosis and to assess the extent and stage of the disease.

Lower mid third and lower third growths were submitted for surgery after respectability was assessed by CT scanning. Of the 24 patients thus submitted for surgery, only 10 had resectable growths; 8 patients underwent transhiatal oesophagectomy and 2 underwent Ivor Lewis Oesophagectomy.

Post-operatively, they were followed up closely until discharge and then at weekly intervals for 8 weeks.

Other patients who had unresectable disease were given external beam radiotherapy with or without feeding Gastrostomy/Jejunostomy. Patients with metastatic disease and those with poor performance status were just given supportive care.

\section{RESULTS OF THE STUDY}

Incidence of $\mathrm{Ca}$ oesophagus was more common in males with a M:F incidence ratio of 3.5:1

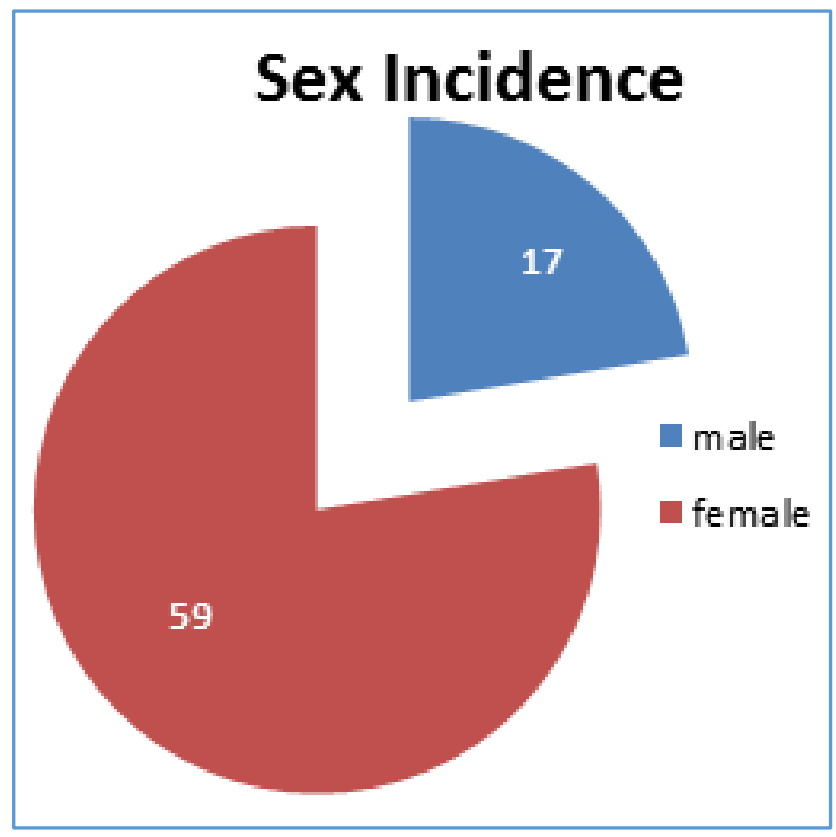

Maximum incidence was in the $6^{\text {th }}$ followed by $5^{\text {th }}$ decades.

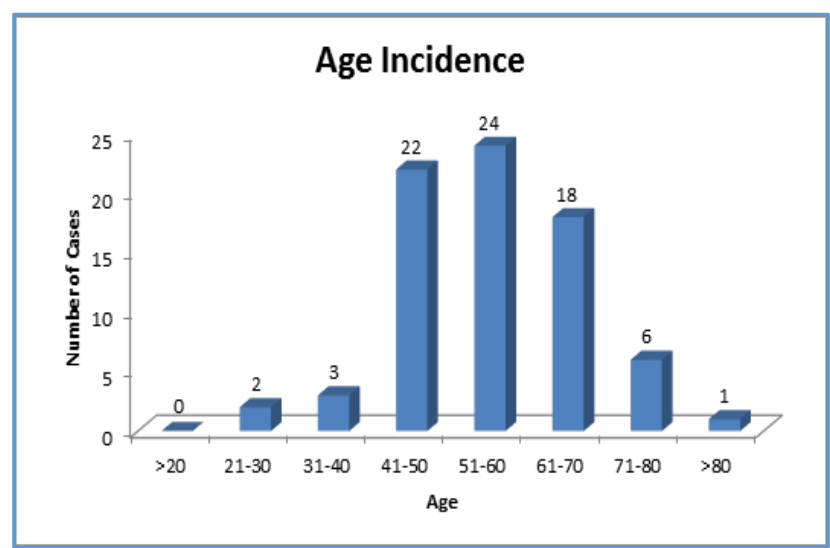

In the study, it was found the maximum incidence in $5^{\text {th }}$ decade for male and $6^{\text {th }}$ decade for female.

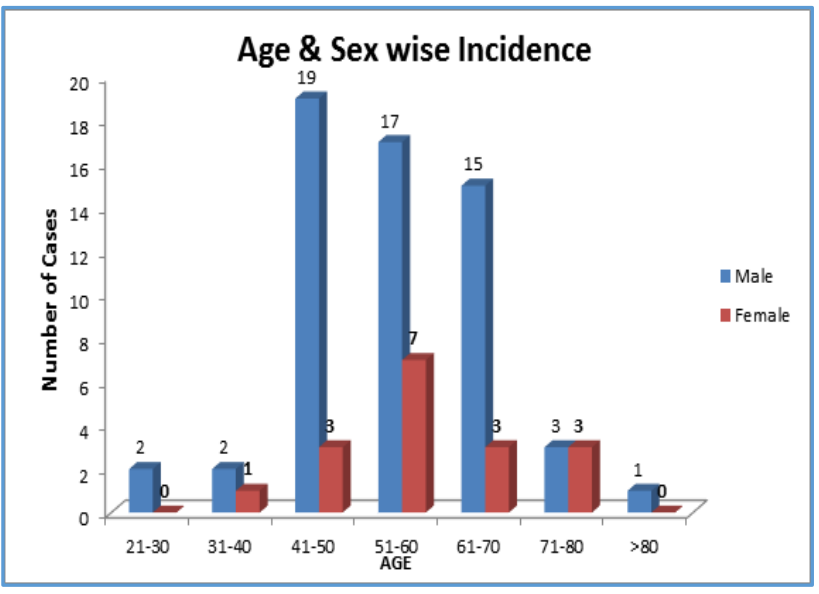

Dysphagia was the most common presenting symptom seen in $94 \%$ of the patients. Weight loss and anorexia were also common symptoms present in $70 \%$ of the patients. Other symptoms seen were regurgitation of food in $42 \%$, recurrent respiratory infections and pneumonia in $18 \%$ of the patients. Cough and hoarseness of voice was seen in $12 \%$ of patients, odynophagia in $8 \%$ and gastrointestinal bleed was a rare feature seen in $2 \%$ of patients.

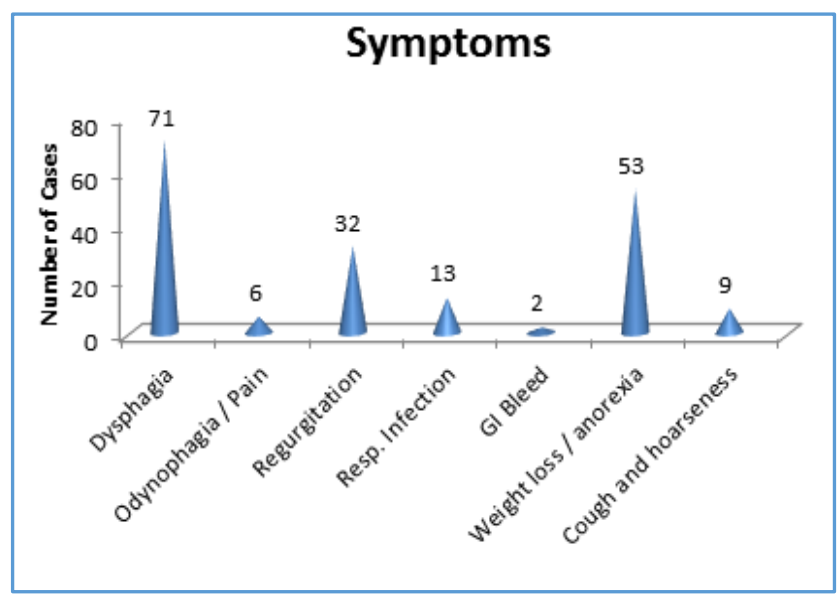

\begin{tabular}{|c|c|c|}
\hline Dysphagia & 71 & $94 \%$ \\
\hline Odynophagia/Pain & 6 & $08 \%$ \\
\hline Regurgitation & 32 & $42 \%$ \\
\hline Resp. Infection & 13 & $18 \%$ \\
\hline GI Bleed & 2 & $2 \%$ \\
\hline Weight Loss/Anorexia & 53 & $70 \%$ \\
\hline Cough and Hoarseness & 9 & $12 \%$ \\
\hline
\end{tabular}

Though incidence of distal oesophageal tumours is increasing worldwide, mid third tumours were more common in this study making up to $50 \%$ of the cases. Lower third tumour were next common making up 33\% and upper third tumours were least common making up $17 \%$ of the total cases. 


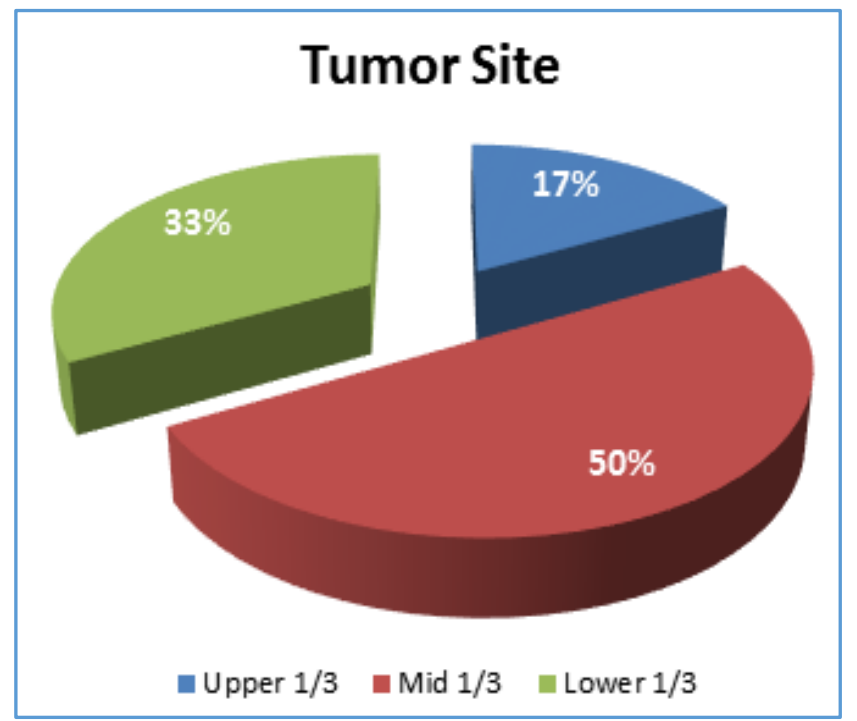

\begin{tabular}{|c|c|c|}
\hline Upper $1 / 3$ & 12 & $17 \%$ \\
\hline Mid $1 / 3$ & 38 & $50 \%$ \\
\hline Lower $1 / 3$ & 26 & $33 \%$ \\
\hline
\end{tabular}

Among the histological types, adenocarcinoma and squamous cell carcinoma were the only 2 types encountered. Despite the increasing incidence of adenocarcinoma in the western countries, squamous cell histology remained the predominant type seen in 67 (89\%) of the patients. Adenocarcinoma was seen in only $9(11 \%)$ of the patients.

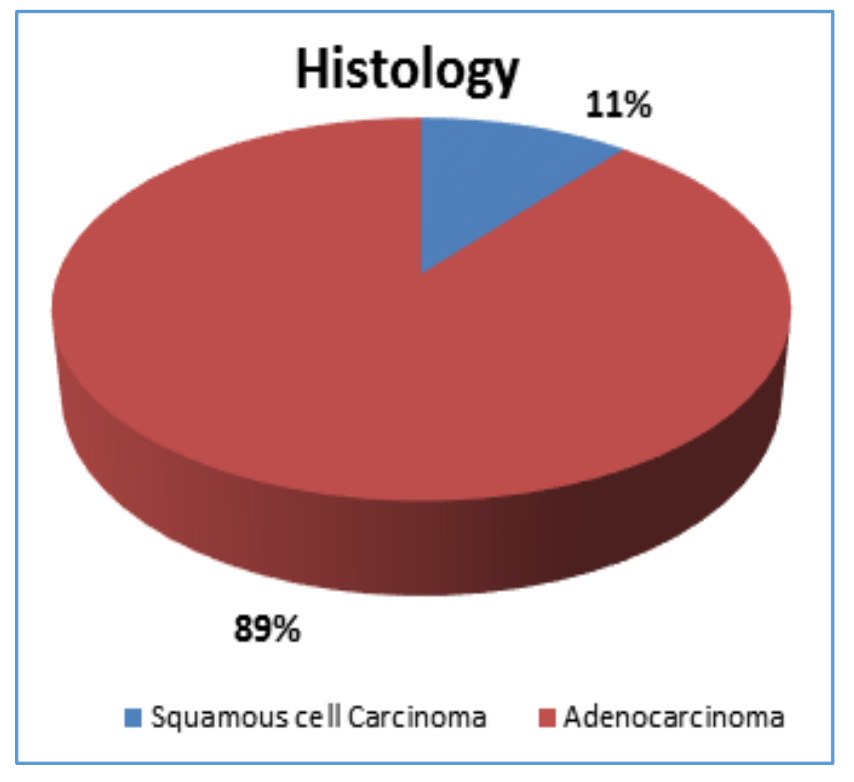

Resectability rate was very poor in our study. Only 8 patients could be taken up for Transhiatal oesophagectomy and 2 for Ivor Lewis Thoracoabdominal resections. Majority of the patients (66) had unresectable disease.

Of those with unresectable disease, 38 were given palliative external beam Radiotherapy with or without Feeding Gastrostomy/Jejunostomy based on their level of Dysphagia; 28 patients who had either metastatic disease or poor performance status were offered supportive care with pain relief and enteral nutrition through a feeding Gastrostomy/Jejunostomy/Endoluminal stenting procedures where appropriate.

\section{Treatment Offered}

A. Surgical resection

1. Transhiatal oesophagectomy 8

2. Ivor Lewis oesophagectomy 2

B. External RT/CT

C. Supportive Care

(FG/FJ/RT Feeding/Pain relief/Endoluminal Procedures).

\section{Post-op Complications}

On following up the operated patients, complications were encountered which included a mortality rate of $10 \%$ which was due to anastomotic leak (In a patient post Ivor-Lewis Oesophagectomy). Pulmonary complications were encountered in $40 \%$ patients. Haemorrhage was encountered in $30 \%$ patients. Reflux was noted in $20 \%$ patients and could be managed conservatively.

\section{Complication}

\begin{tabular}{|c|c|}
\hline Mortality & $1(10 \%)$ \\
\hline Pulmonary complications & $4(40 \%)$ \\
\hline Haemorrhage & $3(3 \%)$ \\
\hline Reflux & $2(20 \%)$ \\
\hline
\end{tabular}

\section{DISCUSSION}

In this study, on analysis of the cases of carcinoma oesophagus admitted at $\mathrm{CMCH}$ it was seen that the disease is more prevalent among the males. (M:F-3.5:1) which is similar to the incidence in western countries. (In the U.S. M.F. - 4:1).(1)

The peak age of incidence was the sixth decade followed next by the $5^{\text {th }}$ decade, which is similar to the incidence worldwide.(2)

On analysing the symptoms at presentation, it was seen that Dysphagia was the most common presenting symptom (94\%) along with weight loss and anorexia (70\%). This correlates well with international statistics.(3) Symptoms of Ca oesophagus and cardia.(3)

\begin{tabular}{|c|c|}
\hline Dysphagia & $85.4 \%$ \\
\hline Weight loss & $60.9 \%$ \\
\hline Pain & $26.5 \%$ \\
\hline Regurgitation & $22.8 \%$ \\
\hline Hoarseness & $4.4 \%$ \\
\hline Cough & $2.5 \%$ \\
\hline & $(\mathrm{N}=907)$ \\
\hline
\end{tabular}

The commonest site of incidence was the mid third, $50 \%$ of the oesophagus in this study followed by lower third (Which includes OG junction growth) 33\% upper third tumours were least common $17 \%$. This differs from western literature where the reported commonest site of incidence is the lower third making up 55\% of the total tumours followed only by mid third, which make up 37\%. Upper third tumours were rare (9\%). $(4,5,6)$

Adenocarcinomas of the oesophagus and cardia are relatively common in the Western hemisphere. The reported incidence of these cancers is increasing in the United States at a rate surpassing that of any other cancer. However, Squamous cell carcinomas are the most common histological type of carcinoma oesophagus worldwide.(7,8,9,10) In this study, squamous cell carcinoma was the predominant histology 
forming $89 \%$ of the tumours. The remaining $11 \%$ were Adenocarcinomas.

Presentation with carcinoma oesophagus was late in this study, majority presenting with either locally advanced or metastatic disease $(80 \%)$. This correlates well, but is higher than in Western studies, where the presentation with advanced disease varied from $60-75 \% .(9,10,11,12,13)$

\section{CONCLUSION}

1. Incidence of carcinoma oesophagus is more common in males.

2. Maximum incidence is in the $6^{\text {th }}$ decade followed by the $5^{\text {th }}$ decade.

3. Dysphagia and weight loss are the most common, but late presenting features.

4. Most common site of presentation is in the middle third in our population.

5. Squamous cell carcinoma still remains the predominant histological variety in our population.

6. Carcinoma oesophagus has an aggressive behaviours and usually presents in late stages with a low rate of respectability.

7. Even with incurable disease, resection can offer superior palliation with restoration of swallowing.

8. Transhiatal resection offers comparable results to transthoracic resection with lower operative risk.

\section{REFERENCES}

1. Landis SH, Murray T, Bolden S, et al. Cancer statistics. CA cancer J clin 1998;48(1):6-29.

2. Wang PV, Chien KV. Surgical treatment of carcinoma of the oesophagus and cardio. Ann Thoracic surg 1993;35:143.

3. Galandiuk S, Hermann RE, Cosgrove DM, et al. Cancer of the oesophagus. Ann Sugr 2001;203:102.

4. NCCN clinical practice guidelines in oncology. Oesophageal and oesophagogastric junction cancers (Excluding the proximal $5 \mathrm{~cm}$ of the stomach). Available at

http://www.nccn.org/professionals/physician_gls/pdf/ esophageal.pdf. Accessed: May 14, 2012.
5. Suzuki A, Xiao L, Hayashi Y, et al. Prognostic significance of baseline positron emission tomography and importance of clinical complete response in patients with oesophageal or gastro-oesophageal junction cancer treated with definitive chemoradiotherapy. Cancer 2011;117(21):4823-33.

6. Gillies RS, Middleton MR, Han C, et al. Role of positron emission tomography-computed tomography in predicting survival after neoadjuvant chemotherapy and surgery for oesophageal adenocarcinoma. Brit J Surg 2012;99(2):239-45.

7. Prins MJ, Ruurda JP, van Diest PJ, et al. The significance of the HER-2 status in oesophageal adenocarcinoma for survival: an immunohistochemical and an in situ hybridization study. Ann Oncol Jan 18, 2013.

8. Nelson R. New clinical guidelines issued for oesophageal cancer. Medscape Medical News Accessed: July 16, 2013.

9. Varghese TK, Hofstetter WL, Rizk NP, et al. The society of thoracic surgeons guidelines on the diagnosis and staging of patients with oesophageal cancer. Ann Thorac Surg 2013;96(1):346-56.

10. Boring CC, Squires TS, Tong T, et al. Cancer statistics. CA cancer J Clin 1994;44(1):7-26.

11. Ferguson MK. Carcinoma of oesophagus in Zuidema GD, Yeo JY, (eds) Surgery of the alimentary tract. New York, Saunders WB, 2002;p 317.

12. Blot WJ, Devesa SS, Kneller RW, et al. Rising incidence of adenocarcinoma of the oesophagus and gastric cardia. JAMA 1991;265(10):1287-9.

13. Pera M, Cameron AJ, Trantek VF, et al. Increasing incidence of adenocarcinoma of the oesophagus and oesophagogastric junction. Gastroenterology 1993;104(2):510-3. 